\title{
The effects of recombinant human IGF-I administration on concentrations of acid labile subunit, IGF binding protein-3, IGF-I, IGF-II and proteolysis of IGF binding protein-3 in adolescents with insulin-dependent diabetes mellitus
}

\author{
T D Cheetham, J M P Holly ${ }^{1}$, R C Baxter ${ }^{2}$, K Meadows ${ }^{1}$, J Jones, \\ A M Taylor and D B Dunger \\ Department of Paediatrics, John Radcliffe Hospital, Headington, Oxford, UK, 'Department of Medicine, Bristol Royal Infirmary, Bristol, UK and ${ }^{1}$ Kolling Institute \\ of Medical Research, St Leonards, New South Wales, Australia \\ (Requests for offprints should be addressed to D Dunger, Department of Paediatrics, John Radcliffe Hospital, Headington, Oxford OX3 9DU, UK)
}

\begin{abstract}
The long term therapeutic potential of recombinant human (rh) IGF-I administration in insulin-dependent diabetes mellitus (IDDM) may be determined by changes in the IGF binding proteins (IGFBPs) and thus the bioavailability of IGF-I. We have therefore studied the effects of a single subcutaneous dose of rhIGF-I $(40 \mu \mathrm{g} / \mathrm{kg}$ at $1800 \mathrm{~h}$ ), when compared with an untreated control night, in 17 subjects with IDDM, on serum concentrations of IGF-I, IGF-II, IGFBP-3, acid labile subunit (ALS), and IGFBP-3 proteolysis.

Mean ( \pm s.E.M.) IGF-I levels increased from $242 \pm$ $30 \mathrm{ng} / \mathrm{ml}$ to $399 \pm 26 \mathrm{ng} / \mathrm{ml}(P=0 \cdot 01)$ after rhIGF-I whereas IGF-II levels declined from $600 \pm 45 \mathrm{ng} / \mathrm{ml}$ to $533 \pm 30 \mathrm{ng} / \mathrm{ml}$. There was a small overnight reduction in baseline ALS levels from $48 \pm 2 \cdot 8$ to $44.5 \pm 3 \cdot 2 \mu \mathrm{g} / \mathrm{ml}$ $(P=0 \cdot 04)$ after rhIGF-I administration. An early fall in IGFBP-3 concentrations on the control night was not seen after rhIGF-I and overall mean levels were increased
\end{abstract}

$(5 \cdot 2 \pm 0 \cdot 2 \mu \mathrm{g} / \mathrm{ml}$ vs $4 \cdot 9 \pm 0 \cdot 2 \mu \mathrm{g} / \mathrm{ml}, \quad P=0 \cdot 04$, on the control night). On the baseline night, IGFBP-3 levels correlated with the sum of IGF-I and IGF-II $(r=0 \cdot 73$, $P=0.02)$ and with levels of the ALS $(r=0 \cdot 7, P=0 \cdot 002)$. However after rhIGF-I, the sum of IGF-I and IGF-II no longer correlated with IGFBP-3, whereas the relationship with ALS was maintained. Immunoblot studies in six subjects indicated that $60 \%-70 \%$ of the IGFBP-3 was detected as a low molecular weight fragment at $1900 \mathrm{~h}$ on both study nights, but the amount of fragment declined to approximately $50 \%$ at $0100 \mathrm{~h}$ and $45 \%$ at $0700 \mathrm{~h}$.

In conclusion, despite a slight but significant fall in ALS, IGFBP-3 levels rise after rhIGF-I administration in IDDM. This cannot be explained by alterations in IGFBP-3 proteolysis, and may relate to the relative stability of ALS/IGFBP-3 when complexed principally with IGF-I rather than IGF-II.

Journal of Endocrinology (1998) 157, 81-87

\section{Introduction}

The insulin-like growth factors (IGF)-I and -II circulate bound to a series of six high affinity IGF binding proteins (IGFBP-1 to -6) which regulate their bioavailability and bioactivity (Ballard et al. 1989, 1992). IGFBP-3, combined with either IGF-I or IGF-II and an acid labile subunit (ALS), provides a circulating reservoir of IGFs which is retained in the circulation (Baxter et al. 1989). The half-life of unbound IGF-I is around 10 to $12 \mathrm{~min}$ whereas the half-life of the ternary complex is approximately $15 \mathrm{~h}$ (Guler et al. 1989). The complex has a molecular mass of approximately $150 \mathrm{kDa}$ and contains the majority of circulating IGFs with the remainder circulating as binary complexes with IGFBP-3 and other binding proteins (Binoux \& Hossenlopp 1988, Baxter \& Martin 1989).
Serum proteases identified during pregnancy, severe illness and after surgery may alter the affinity with which the IGFs are bound in these complexes and hence IGF bioavailability (Hossenlopp et al. 1990, Davies et al. 1991, Cwyfan-Hughes et al. 1992, Davenport et al. 1992).

In patients with insulin-dependent diabetes mellitus (IDDM) IGF-I levels are invariably low or in the low normal range (Amiel et al. 1984, Taylor et al. 1988) even though growth hormone (GH) hypersecretion has been well documented (Edge et al. 1990, Batch \& Werther 1992). There is little detailed observation of the kinetics of the binding proteins and the ALS in IDDM although circulating levels of IGFBP-3 are low and IGFBP-1 may be increased (Batch et al. 1991). There is good evidence to indicate that the reductions in IGF-I and the elevations in IGFBP-1 arise because of inadequate portal delivery of 
Table1 Subject characteristics

\begin{tabular}{lcc} 
& Range & Median \\
\cline { 2 - 2 } Age (years) & $13 \cdot 5-18 \cdot 9$ & $15 \cdot 5$ \\
Diabetes duration (years) & $3 \cdot 0-13 \cdot 8$ & $5 \cdot 9$ \\
C-peptide $(\mathrm{pmol} / \mathrm{l})^{*}$ & $20-270$ & 50 \\
$\mathrm{BMI}\left(\mathrm{kg} / \mathrm{m}^{2}\right)$ & $18 \cdot 8-29 \cdot 42$ & $22 \cdot 3$ \\
Insulin dose $(\mathrm{U} / \mathrm{kg})$ & $0 \cdot 73-1 \cdot 43$ & $1 \cdot 05$ \\
\hline
\end{tabular}

*Blood glucose $>7.0 \mathrm{mmol} / \mathrm{l}$.

insulin (Brismar et al. 1994). The hepatic GH receptor is partially insulin-dependent (Baxter et al. 1980) and circulating levels of the $\mathrm{GH}$ binding protein (GHBP) are reduced in IDDM (Menon et al. 1992, Holl et al. 1993). Improved insulinisation leads to increased levels of GHBP and IGF-I with reductions in IGFBP-1 (Amiel et al. 1984, Brismar et al. 1994). The administration of insulin to newly diagnosed patients also affects circulating IGFBP-3 protease activity (Bereket et al. 1995). It therefore seems likely that insulin may have an important role as a regulator of IGF-I production and of the kinetics and distribution of IGFs between the different IGFBPs.

The subcutaneous administration of low doses of recombinant human (rh) IGF-I to adolescents with IDDM has been shown to increase IGF-I levels and to reduce GH hypersecretion and the insulin infusion requirements for the maintenance of euglycaemia (Cheetham et al. 1993, 1994a). A corresponding fall in IGF-II levels and an increase in IGFBP-3 concentrations were also observed in these studies (Cheetham et al. 1994b). We now report a more detailed examination of the effects of rhIGF-I on IGF-I, IGF-II, IGFBP-3, ALS, and IGFBP-3 proteolysis in overnight studies of rhIGF-I administration.

\section{Subjects and Methods}

Seventeen subjects with IDDM took part in these studies. There were 13 females and 4 males aged from 13.5-18.9 years (median 15.5). All had been diagnosed for at least $3 \cdot 0$ years and were in mid-late puberty stages 4 to 5 (Tanner 1962) with body mass indices ranging from $18 \cdot 8-29 \cdot 4 \mathrm{~kg} /$ $\mathrm{m}^{2}$ (median 22.3). Stimulated C-peptide concentrations (blood glucose $>7.0 \mathrm{mmol} / \mathrm{l}$ ) ranged from 20-270 pmol/1 (median $50 \mathrm{pmol} / \mathrm{l}$ ). The daily insulin dose ranged from $0 \cdot 73-1.43 \mathrm{U} / \mathrm{kg}$ (median $1.05 \mathrm{U} / \mathrm{kg}$ ). Subject characteristics are detailed in Table 1.

\section{Protocol}

Subjects were admitted for two separate nights and randomly allocated to a treatment group with rhIGF-I administered in the thigh in a s.c. dose of $40 \mu \mathrm{g} / \mathrm{kg}$ or a control group (control night) when either no injection $(n=8)$ or a placebo $(n=9)$ was administered. Subjects stopped all intermediate-acting insulin $36 \mathrm{~h}$ before the study began. Between then and admission to hospital blood glucose concentrations were controlled with four daily injections of soluble insulin. The last subcutaneous insulin dose was at lunch-time on the day of admission.

Subjects were admitted to hospital between $1600 \mathrm{~h}$ and $1700 \mathrm{~h}$ on the day of the study. Cannulae were inserted into distal forearm and antecubital fossa veins following the application of local anaesthetic cream. The forearm was maintained in a heated box to arterialise the venous samples obtained from the forearm cannula. The proximal cannula was used to administer a continuous insulin infusion to maintain euglycaemia overnight.

Samples for IGF-I and IGFBP-3 estimation were taken every hour and every three hours respectively during the single bolus studies. ALS concentrations were determined in samples taken at $1800 \mathrm{~h}$ and $0800 \mathrm{~h}$.

IGF-II was determined in samples taken two-hourly on both nights in the nine subjects who were part of the placebo-controlled trial.

\section{Assays}

Plasma samples for IGF-I were acid ethanol extracted and IGF-I concentrations determined by radioimmunoassay as described previously (Taylor et al. 1990). The intra-assay coefficients of variation were $5 \cdot 2 \%$ and $4 \cdot 8 \%$ at analyte levels of 27.5 and $220 \mathrm{ng} / \mathrm{ml}$ respectively. The interassay coefficients of variation were $12.7 \%$ and $10.6 \%$ at analyte levels of 77 and $242 \mathrm{ng} / \mathrm{ml}$ respectively.

Serum IGFBP-3 levels were determined using a double antibody RIA. IGFBP-3 antiserum (SCH-2/5) was used at a final concentration of 1:8000. Recombinant glycosylated IGFBP-3 (Celtrix Pharmaceuticals, Santa Clara, CA, USA) was used for standards, giving a range of $5-500 \mathrm{ng} / \mathrm{ml}$. Bound and free ${ }^{125}$ I-labelled glycosylated IGFBP-3 were separated using a donkey anti-rabbit SAC-CEL second antibody (I.D.S. Ltd, Bolden Business Park, Bolden, Tyne and Wear, UK). The interassay coefficient of variation was $4 \cdot 28 \%$ at $5 \mu \mathrm{g} / \mathrm{ml}$ and the intra-assay coefficient of variation was $5 \cdot 14 \%$ at $5 \mu \mathrm{g} / \mathrm{ml}$.

The ALS was measured by a specific RIA using an antiserum raised in New Zealand white rabbits following the injection of purified human ALS. Serum samples were incubated with antiserum, ${ }^{125}$ I-labelled ALS and RIA buffer (Baxter 1990). The standard curve was derived from incubations containing pure alpha-subunit. Bound and free ${ }^{125}$ I-labelled ALS were separated and counted after the addition of goat anti-rabbit immunoglobulin and normal rabbit serum. The intra-assay coefficients of variation were $3 \cdot 4 \%$ at $5 \cdot 1 \mu \mathrm{g} / \mathrm{ml}, 3 \cdot 3 \%$ at $20 \cdot 8 \mu \mathrm{g} / \mathrm{ml}$ and $3.4 \%$ at $42 \cdot 7 \mu \mathrm{g} / \mathrm{ml}$. The interassay coefficients of variation were $10 \cdot 5 \%$ at $5 \cdot 3 \mu \mathrm{g} / \mathrm{ml}, 5 \cdot 4 \%$ at $24 \cdot 0 \mu \mathrm{g} / \mathrm{ml}$ and $6.5 \%$ at $57 \cdot 5 \mu \mathrm{g} / \mathrm{ml}$. 
IGF-II concentrations were determined after acid ethanol extraction in the laboratories of Prof. W Blum (University Children's Hospital, Tubingen, Germany) using a specific radioimmunoassay which utilises excess IGF-I to block interference from IGFBPs (Blum et al 1988). The interassay coefficient of variation at $50 \%$ of maximum binding capacity was $12 \cdot 2 \%$ and the minimum detection limit was $0.018 \mathrm{ng}$.

\section{Immunoblot studies}

Immunoblot studies were undertaken to assess protease activity in samples collected at $1900 \mathrm{~h}, 0100 \mathrm{~h}$ and $0700 \mathrm{~h}$ in the six subjects who demonstrated the largest changes in IGFBP-3 overnight when rhIGF-I treatment and control nights were compared. Western immunoblotting was performed as described before (Mason et al. 1996). Serum samples $(2.5 \mu \mathrm{l})$ were separated through a $12.5 \%$ SDSpolyacrylamide gel and then blotted onto a Hybond C-super membrane (Amersham International, Amersham, Bucks, UK). This was blocked with a $5 \%$ powdered milk solution and then probed with the same IGFBP-3 antiserum used in the RIA (SCH-2/6 at 1:15000 dilution). At this dilution this antiserum did not cross-react with recombinant IGFBP-1, IGFBP-2, IGFBP-4, IGFBP-5 or IGFBP-6 loaded onto immunoblots at supraphysiological levels. After washing this was reprobed with secondary (anti-rabbit) antibody conjugated to horseradish peroxidase and the signal visualised by the use of an enhanced chemiluminescence kit according to the instructions supplied by the manufacturer (Amersham International) and exposed to autoradiographic film. Bands on the film were quantitated by laser densitometry. A stack of three films was simultaneously exposed for each blot in order to ensure obtaining an autoradiographic signal within the linear range.

\section{Statistics}

Changes in IGFBP-3, IGF-II and Western immunoblot data were analysed by repeated measures analysis of variance. Parameters at the beginning and end of the study night were compared by paired $t$-tests and separate variables by linear regression. Data are expressed as means \pm s.E.M. and significance has been set at the $5 \%$ level.

\section{Results}

Serum IGF-I concentrations were stable on the control night. Following rhIGF-I administration levels rose promptly reaching a peak after $5 \mathrm{~h}$ and then declined with a half-life of around $18 \mathrm{~h}$. Mean overnight IGF-I concentrations were $242 \pm 20 \mathrm{ng} / \mathrm{ml}$ on the control night and $399 \pm 26 \mathrm{ng} / \mathrm{ml}$ after rhIGF-I administration $(P<0 \cdot 01)$
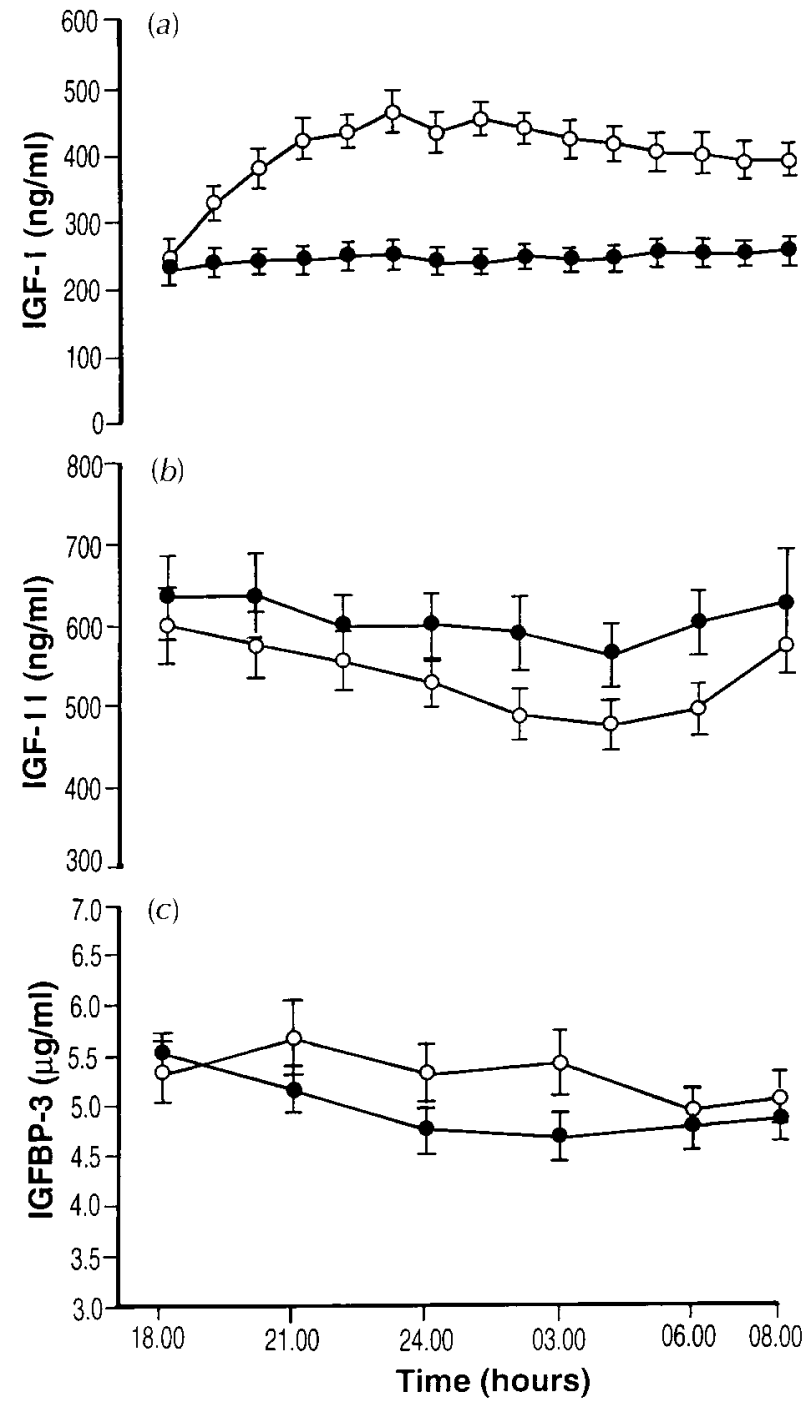

Figure 1 Overnight concentrations of (a) IGF-I, (b) IGF-II, and (c) IGFBP-3 following a single subcutaneous injection of rhIGF-I $(\bigcirc)$ or placebo $(-)$ given at $1800 \mathrm{~h}$.

(Fig. 1). Glucose and insulin data from this group of subjects have been reported elsewhere (Cheetham et al. 1997).

Baseline IGFBP-3 concentrations (1800 h) were similar on the control night and the night of rhIGF-I administration $(5 \cdot 6 \pm 0 \cdot 2$ vs $5 \cdot 3 \pm 0.3 \mu \mathrm{g} / \mathrm{ml} ; P>0 \cdot 1)$. On the control night IGFBP-3 levels subsequently fell between $1800 \mathrm{~h}$ and $0300 \mathrm{~h}$ (from $5 \cdot 6 \pm 0 \cdot 2 \mu \mathrm{g} / \mathrm{ml}$ to $4 \cdot 6 \pm$ $0 \cdot 2 \mu \mathrm{g} / \mathrm{ml}$; Fig. 1). The decline in IGFBP-3 concentrations was not observed on the night of rhIGF-I administration, and overall IGFBP-3 levels were increased $(5 \cdot 2 \pm 0 \cdot 2 \mu \mathrm{g} / \mathrm{ml})$ compared with the control night $(4 \cdot 9 \pm 0 \cdot 2 \mu \mathrm{g} / \mathrm{ml})$ with a significant treatment effect $(P=0 \cdot 03)$. IGFBP-3 data are summarised in Table 2. 
Table 2 IGFBP-3 concentration $(\mu \mathrm{g} / \mathrm{ml})$ in samples from subjects taken over the control night or the night of rhIGF-I administration. Baseline values (at $1800 \mathrm{~h}$ ) and overall mean values

$(1800-0800 \mathrm{~h})$ are shown. Values are means \pm S.E.M. with range in parentheses

\begin{tabular}{|c|c|c|c|}
\hline & Control & rhIGF-I & $P$ value \\
\hline Baseline & $\begin{array}{l}5 \cdot 6 \pm 0 \cdot 2 \\
(4 \cdot 3-7 \cdot 0)\end{array}$ & $\begin{array}{l}5 \cdot 3 \pm 0 \cdot 3 \\
(4 \cdot 0-9 \cdot 4)\end{array}$ & NS \\
\hline Overall mean & $\begin{array}{l}4 \cdot 9 \pm 0 \cdot 2 \\
(3 \cdot 3-6 \cdot 8)\end{array}$ & $\begin{array}{l}5 \cdot 2 \pm 0 \cdot 2 \\
(3 \cdot 9-7 \cdot 5)\end{array}$ & $0 \cdot 04$ \\
\hline
\end{tabular}

NS, not significant

Table 3 ALS concentration $(\mu \mathrm{g} / \mathrm{ml})$ in samples taken at $1800 \mathrm{~h}$ and $0800 \mathrm{~h}$ from control and rhIGF-I-treated subjects. Values are means \pm S.E.M. with range in parentheses

\begin{tabular}{|c|c|c|c|}
\hline & \multicolumn{2}{|l|}{ Time (h) } & \multirow[b]{2}{*}{$P$ value } \\
\hline & 1800 & 0800 & \\
\hline Control & $\begin{array}{c}47 \cdot 8 \pm 3 \cdot 2 \\
(19 \cdot 7-64 \cdot 4)\end{array}$ & $\begin{array}{c}45 \cdot 7 \pm 3 \cdot 1 \\
(27 \cdot 8-75 \cdot 1)\end{array}$ & $0 \cdot 2$ \\
\hline rhIGF-I-treated & $\begin{array}{c}48 \cdot 5 \pm 2 \cdot 8 \\
(24 \cdot 7-70 \cdot 7)\end{array}$ & $\begin{array}{c}44 \cdot 5 \pm 3 \cdot 2 \\
(21 \cdot 2-65 \cdot 1)\end{array}$ & $0 \cdot 04$ \\
\hline
\end{tabular}

There were no differences in the ALS concentrations at $1800 \mathrm{~h}$ on the control and the rhIGF-I treatment nights $(47 \cdot 8 \pm 3 \cdot 2$ vs $48 \cdot 5 \pm 2 \cdot 8 \mu \mathrm{g} / \mathrm{ml}$ respectively). Levels at $0800 \mathrm{~h}$ remained unchanged on the control night $(45.7 \pm 3.1 \mu \mathrm{g} / \mathrm{ml})$ but fell on the night of rhIGF-I administration from $48.5 \pm 2.8$ at $1800 \mathrm{~h}$ to $44.5 \pm$ $3 \cdot 2 \mu \mathrm{g} / \mathrm{ml}$ at $0800 \mathrm{~h}(P=0 \cdot 04)$ (Table 3$)$.

ALS concentrations at $1800 \mathrm{~h}$ and $0800 \mathrm{~h}$ correlated with IGFBP-3 levels in individual subjects on both control and rhIGF-I treatment nights. The respective correlation coefficients were $r=0.63(P=0.008)$ at $1800 \mathrm{~h}$ and $r=0.7$ $(P=0.002)$ at $0800 \mathrm{~h}$ on the control night and $r=0.52$ $(P=0.034)$ at $1800 \mathrm{~h}$ and $r=0.68(P=0.003)$ at $0800 \mathrm{~h}$ on the night of rhIGF-I administration.

IGF-II levels $(n=9)$ have been reported previously (Cheetham et al. 1994b) and were similar at baseline on the two study nights $(626 \pm 48$ vs $609 \pm 40 \mathrm{ng} / \mathrm{ml})$. IGF-II levels tended to decline in both groups during the night to a nadir at $0400 \mathrm{~h}$ (Fig. 1). The decline was more pronounced following rhIGF-I administration, however, and at $0400 \mathrm{~h}$ levels were $473 \pm 32 \mathrm{ng} / \mathrm{ml}$ after rhIGF-I administration compared with $559 \pm 40 \mathrm{ng} / \mathrm{ml}$ on the control night. Overall mean IGF-II levels between $1800 \mathrm{~h}$ and $0800 \mathrm{~h}$ were $600 \pm 45 \mathrm{ng} / \mathrm{ml}$ on the control night compared with $533 \pm 30 \mathrm{ng} / \mathrm{ml}$ after rhIGF-I $(P=0 \cdot 06)$.

In the subjects in whom IGF-II levels were measured $(n=9)$ it was possible to examine the relationship between IGF-I, IGF-II, IGFBP-3 and ALS concentrations. In order to determine the relationships between the sum of IGF-I and IGF-II and IGFBP-3, concentrations of these peptides were converted into molar equivalents. There were strong

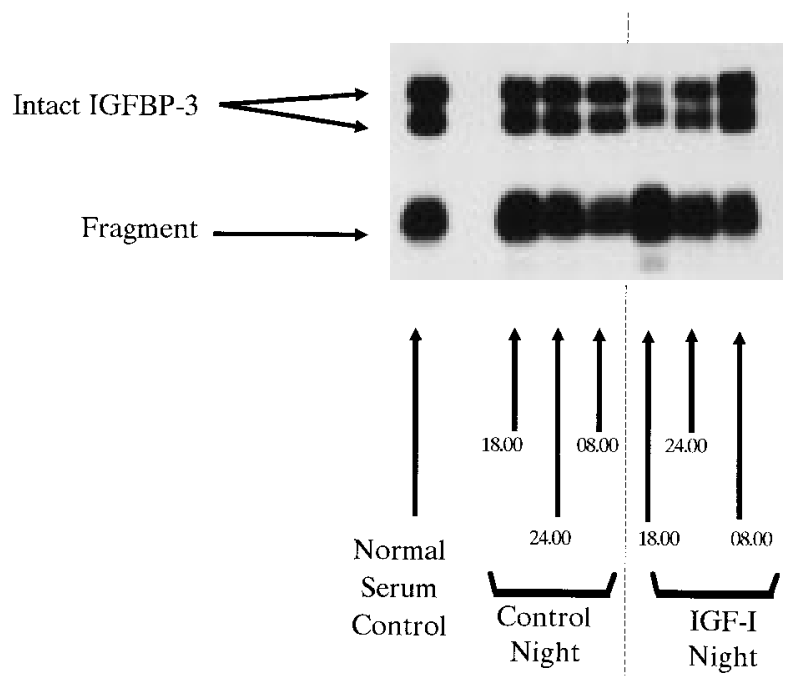

Figure 2 Western immunoblot showing forms of IGFBP-3 in samples taken over the control night and the night of rhIGF-I administration in one of the subjects. The top two bands represent differentially glycosylated forms of intact IGFBP-3 whilst the lower band represents the major fragment resulting from specific proteolysis.

correlations between the sum of IGF-I and IGF-II concentrations and the levels of IGFBP-3 throughout the control night $(r=0.73, P=0 \cdot 02)$, whereas this relationship was perturbed following rhIGF-I administration $(r=0 \cdot 49$, $P=0 \cdot 17)$.

The sum of IGF-I and IGF-II concentrations was also related to ALS concentrations in the $1800 \mathrm{~h}$ sample on both nights $(r=0 \cdot 8, P=0 \cdot 01)$. However this relationship was not observed in the $0800 \mathrm{~h}$ sample on either control nights $(r=0 \cdot 22, P=0 \cdot 5)$ or on the morning after rhIGF-I administration $(r=0 \cdot 24, P=0 \cdot 2)$.

\section{Immunoblot studies}

Representative immunoblots from one subject are illustrated in Fig. 2. Densitometry analysis of immunoblots from six subjects is illustrated in Fig. 3. At $1900 \mathrm{~h}$ on both study nights, $60-70 \%$ of the IGFBP-3 was detected as a low molecular weight fragment, but by $0100 \mathrm{~h}$ the amount of fragment had declined to around $50 \%$ and by $0700 \mathrm{~h}$ it had declined further to around 45\%. A significant decline in the amount of fragmented IGFBP-3 was observed on both control nights (ANOVA, $P<0.006$ ) and rhIGF-I treatment nights (ANOVA, $P<0.001$ ) but with no difference between nights.

\section{Discussion}

Recombinant human IGF-I administration to adolescents with IDDM, in a relatively low dose of $40 \mu \mathrm{g} / \mathrm{kg}$ s.c. leads 


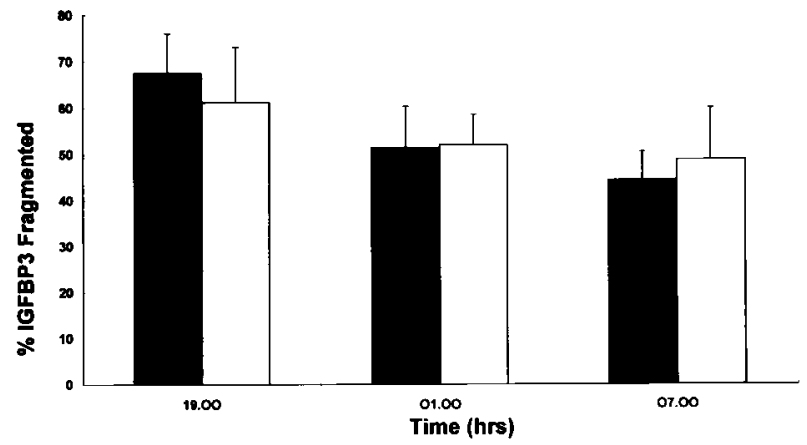

Figure 3 Densitometry analysis of immunoblots from six subjects represented as mean percentage ( \pm s.D.) of IGFBP-3 fragments at $1900 \mathrm{~h}, 0100 \mathrm{~h}$ and $0700 \mathrm{~h}$ on nights when rhIGF-I (solid bars) or placebo (open bars) was administered.

to restoration of normal physiological levels of IGF-I and can be given as a single subcutaneous dose (Cheetham et al. 1993). In preliminary studies it was demonstrated that small but significant increases in IGFBP-3 concentrations could also be observed (Cheetham et al. 1994b) and we have now confirmed this in a larger group of adolescents with IDDM. There are two possible mechanisms whereby this increase in IGFBP-3 could have occurred. There could be increased production of IGFBP-3 or rhIGF-I could alter the relative concentrations of the components of the $150 \mathrm{kDa}$ IGF/IGFBP-3/ALS complex and its stability in the plasma.

Formation of the $150 \mathrm{kDa}$ ternary complex is dependent on the presence of the GH-dependent ALS (Baxter \& Martin 1989, Baxter et al. 1989). ALS circulates in excess in diabetic rats and normal human subjects (Baxter 1988, Lewitt et al. 1993) and baseline ALS concentrations were relatively high in the group of adolescent subjects with IDDM that were studied. Whilst concentrations remained unchanged on the control night, there was a small reduction in ALS overnight following rhIGF-I treatment. This might result from the consistent fall in $\mathrm{GH}$ concentrations that we have observed following rhIGF-I (Cheetham et al. 1993) and may provide further support for the relationship between GH levels and circulating ALS (Baxter 1990).

Despite the modest fall in ALS concentrations, IGFBP3 levels tended to rise after rhIGF-I. A clear relationship between IGFBP-3 and the ALS was evident both before and after the administration of rhIGF-I, suggesting that the modest reduction in ALS levels was not limiting the amount of IGFBP-3 which could be retained in the circulation. The relationship between ALS and the sum of IGF-I and IGF-II concentrations was observed on both nights in the $1800 \mathrm{~h}$ sample but not in the $0800 \mathrm{~h}$ sample, again indicating that complex formation may not be stable overnight in IDDM.

The regulation of IGFBP-3 production is complex. Although originally described as GH-dependent (Baxter \& Martin 1989) evidence from in situ hybridisation indicates that in the liver IGFBP-3 is not expressed by hepatocytes but by perisinusoidal cells (Chin et al. 1994). As these cells do not appear to express $\mathrm{GH}$ receptors this indicates that any effect of GH on IGFBP-3 production should be indirect (Kanety et al. 1993). However administration of GH to rats causes a rapid induction of hepatic IGFBP3 mRNA whereas administration of IGF-I has no such acute effect (Lemmey et al. 1994). rhIGF-I administration to normal human subjects leads to a fall in both the levels of ALS and IGFBP-3 (Baxter et al. 1993, Kupfer et al. 1993) whilst administration of rhIGF-I to subjects with $\mathrm{GH}$ insensitivity has not been found to increase circulating IGFBP-3 concentrations in some studies but has in others (Gargosky et al. 1993, Kanety et al. 1993). Our observation of a small increase in IGFBP-3 following administration of rhIGF-I to adolescents with IDDM occurred despite GH suppression and a fall in ALS levels. Furthermore, the rise in IGFBP-3 that we observed represented, in part, a reversal of the decline in IGFBP-3 levels on the control night. One possible explanation for these observations is that rhIGF-I had led directly or indirectly to an altered stability of the $150 \mathrm{kDa}$ complex.

The circulating concentration of IGFBP-3, like that of IGFs, depends on the proportion which can associate into larger complexes. Uncomplexed IGFBP-3 has a very short half-life but when bound with IGF and ALS its half-life is prolonged. Circulating protease activity may alter the stability of the ternary complex. Our immunoblot studies demonstrated that a large percentage of the IGFBP-3 was fragmented (around 60\%) at the beginning of each study night. This is in keeping with previous observations of increased proteolysis of IGFBP-3 in subjects with type 2 diabetes and untreated patients with IDDM (Bereket $e t$ al. 1995). Recent data have highlighted the importance of insulin in the regulation of IGFBP-3 protease activity in IDDM (Bereket et al. 1995). The reduction in the amount of proteolysed fragment overnight on both study days may reflect improved insulinisation, as subjects were clamped in the euglycaemic range with an intravenous insulin infusion. However, the increase in IGFBP-3 on the rhIGF-I treatment night cannot be explained by changes in protease activity. It may relate to differences in the stability of tertiary complexes when formed with IGF-I rather than IGF-II and IGF-I (Holman \& Baxter 1996) as IGF-II levels declined after rhIGF-1 administration.

The increases in IGFBP-3 during these bolus studies was not sufficient to explain the sustained rises in IGF-I levels that we observed, even when allowance is made for the corresponding fall in IGF-II. Whilst the relationship between the sum of IGF-I and IGF-II with IGFBP-3 was evident on the control nights and at the beginning of the rhIGF-I treatment night, this relationship was perturbed after rhIGF-I administration. It has been shown that, following rhIGF-I administration, although most of the IGF-I is carried in the large molecular weight form, increases can also be observed in the $40-50 \mathrm{kDa}$ range 
(Cheetham et al. 1994b). Changes in free IGF-I after a dose of $40 \mu \mathrm{g} / \mathrm{kg}$ are relatively small (Cheetham et al. 1994b). The IGF-I carried in the $40-50 \mathrm{kDa}$ group may represent IGF bound to fragmented IGFBP-3 but it could also represent significant binding to IGFBP-1, IGFBP-2 or other IGFBPs. Direct measurement of the proportions of IGF-I and IGF-II bound in individual IGFBP complexes will be needed to resolve these issues.

Further study of the effects of rhIGF on IGFBP-1 and IGFBP-2 are clearly indicated. It has yet to be determined whether sustained increases in IGFBP-3 and greater stability of the $150 \mathrm{kDa}$ complex will be observed with long term rhIGF-I therapy but this may be an important factor in determining the therapeutic potential of this peptide in adolescents with IDDM.

\section{Acknowledgements}

T D C was supported by a grant from Pharmacia, Stockholm, Sweden. We would like to thank Pharmacia for providing the recombinant IGF-I used in these studies. We are also grateful to Dr C Maack (Celtrix Pharmaceuticals, Inc.) for the generous gift of recombinant IGFBP-3 used for the RIA in this study. Assistance from Sally Strang, Dot Harris and the Pharmacy Department at the John Radcliffe Hospital and from Mark Pearce of the Department of Child Health, Newcastle-upon-Tyne is gratefully acknowledged.

\section{References}

Amiel SA, Sherwin RS, Hintz RL, Gertner JM, Press CM \& Tamborlane WV 1984 Effect of diabetes and its control on insulinlike growth factors in the young subject with type- 1 diabetes. Diabetes 33 1175-1179.

Ballard J, Baxter R, Binoux M, Clemmons D, Drop S, Hall K, Hintz R, Rechler M, Rutanen E \& Schwander J 1989 On the nomenclature of the IGF binding proteins. Acta Endocrinologica 121 751-752.

Ballard FJ, Baxter RC, Binoux M, Clemmons DR, Drop LS, Hall K, Hintz RL, Ling N, Mohan S, Rechler MM et al. 1992 Report on the nomenclature of the IGF binding proteins. Journal of Clinical Endocrinology and Metabolism 74 15-16.

Batch JA \& Werther GA 1992 Changes in growth hormone concentrations during puberty in adolescents with insulindependent diabetes. Clinical Endocrinology 36 411-416.

Batch JA, Baxter RC \& Werther G 1991 Abnormal regulation of insulin-like growth factor binding proteins in adolescents with insulin-dependent diabetes. Journal of Clinical Endocrinology and Metabolism 73 964-968.

Baxter RC 1988 Characterization of the acid-labile subunit of the growth hormone-dependent insulin-like growth factor binding protein complex. Journal of Clinical Endocrinology and Metabolism 67 265-272.

Baxter RC 1990 Circulating levels and molecular distribution of the acid-labile (a) subunit of the high molecular weight insulin-like growth factor-binding protein complex. Journal of Clinical Endocrinology and Metabolism 70 1347-1353.
Baxter RC \& Martin JL 1989 Structure of the 140000 growthhormone dependent insulin-like growth factor binding protein complex: determination by reconstitution and affinity-labeling. Proceedings of the National Academy of Sciences of the USA $\mathbf{8 6}$ 6898-6902.

Baxter RC, Bryson JM \& Turtle JR 1980 Somatogenic receptors of rat liver: regulation by insulin. Endocrinology 107 1176-1181.

Baxter RC, Martin JL \& Beniac VA 1989 High molecular weight insulin-like growth factor binding protein complex: purification and properties of the acid-labile subunit from human serum. Journal of Biological Chemistry 264 11843-11848.

Baxter RC, Hizuka N, Takano K, Holman SR \& Asakawa K 1993 Responses of insulin-like growth factor binding protein-1 (IGFBP-1) and the IGFBP-3 complex to administration of insulin-like growth factor-I. Acta Endocrinologica 128 101-118.

Bereket A, Lang CH, Blethen SL, Fan J, Frost RA \& Wilson TA 1995 Insulin-like growth factor binding protein-3 proteolysis in children with insulin-dependent diabetes mellitus: a possible role for insulin in the regulation of IGFBP-3 protease activity. Journal of Clinical Endocrinology and Metabolism 80 2282-2288.

Binoux M \& Hossenlopp P 1988 Insulin-like growth factor (IGF) and IGF-binding proteins: comparison of human serum and lymph. Journal of Clinical Endocrinology and Metabolism 67 509-514.

Blum WF, Ranke MB \& Bierich JR 1988 A specific radioimmunoassay for insulin-like growth factor II: the interference of IGF binding proteins can be blocked by excess IGF-I. Acta Endocrinologica 118 374-380.

Brismar K, Fernqvist-Forbes E, Wahren J \& Hall K 1994 Effect of insulin on the hepatic production of insulin-like growth factorbinding protein-1 (IGFBP-1), IGFBP-3 and IGF-I in insulindependent diabetes. Journal of Clinical Endocrinology and Metabolism 79 872-878.

Cheetham TD, Jones J, Taylor AM, Holly J, Matthews DR \& Dunger DB 1993 The effects of recombinant insulin-like growth factor-I administration on growth hormone levels and insulin requirements in adolescents with Type 1-(insulin-dependent) diabetes mellitus. Diabetologia 36 678-681.

Cheetham TD, Clayton KL, Taylor AM, Holly J, Matthews DR \& Dunger DB 1994a The effects of recombinant human insulin-like growth factor-I on growth hormone secretion in adolescents with insulin-dependent diabetes mellitus. Clinical Endocrinology $\mathbf{4 0}$ $515-522$.

Cheetham TD, Taylor A, Holly JMP, Clayton K, Cwyfan-Hughes S \& Dunger DB $1994 b$ The effects of recombinant human insulinlike growth factor-I (IGF-I) administration on the levels of IGF-I IGF-II and IGF-binding proteins in adolescents with insulindependent diabetes mellitus. Journal of Endocrinology 142 367-374.

Cheetham TD, Connors M, Clayton KL, Watts A \& Dunger DB 1997 The relationship between overnight GH levels and insulin concentrations in adolescents with insulin-dependent diabetes mellitus (IDDM) and the impact of recombinant human insulin-like growth factor-I (rhIGF-I). Clinical Endocrinology 46 415-424.

Chin E, Zhou J, Dai J, Baxter RC \& Bondy CA 1994 Cellular localization and regulation of gene expression for components of the insulin-like growth factor ternary binding protein complex. Endocrinology $1342498-2504$.

Cwyfan-Hughes SC, Cotterill AM, Molloy AR, Cassell TB, Braude N, Hinds CJ, Wass JAH \& Holly JMP 1992 The induction of specific proteases for insulin-like growth factor binding proteins following major heart surgery. Journal of Endocrinology 135 135-145.

Davenport ML, Isley WL, Pucilowska JB, Beatty Pemberton L, Lyman B, Underwood LE \& Clemmons DR 1992 Insulin-like growth factor binding protein-3 proteolysis is induced after elective surgery. Journal of Clinical Endocrinology and Metabolism 75 590-595.

Davies SC, Wass JAH, Ross RJM, Cotterill AM, Buchanan CR, Coulson VJ \& Holly JMP 1991 The induction of a specific protease 
for insulin-like growth factor binding protein-3 in the circulation during severe illness. Journal of Endocrinology 130 469-473.

Edge JA, Dunger DB, Matthews DR, Gilbert JP \& Smith CP 1990 Overnight growth hormone concentrations in diabetic compared with normal adolescents. Journal of Clinical Endocrinology and Metabolism 71 1356-1362.

Gargosky SE, Wilson KF, Fielder PJ, Vaccarello MA, Guevara-Aguirre J, Diamond FB, Baxter RC, Rosenbloom AL \& Rosenfeld RG 1993 The composition and distribution of insulin-like growth factors (IGFs) and IGF-binding proteins (IGFBPs) in the serum of growth hormone receptor-deficient patients: effects of IGF-I therapy on IGFBP-3. Journal of Endocrinology and Metabolism 77 1683-1689.

Guler H-P, Zapf J, Schmid C \& Froesch ER 1989 Insulin-like growth factors-I and -II in healthy man: estimation of half-lives and production rates. Acta Endocrinologica 121 753-758.

Holl RH, Siegler B, Scherbaum WA \& Heinze E 1993 The serum growth hormone-binding protein is reduced in young patients with insulin-dependent diabetes mellitus. Journal of Clinical Endocrinology and Metabolism 76 165-167.

Holman SR \& Baxter RC 1996 Insulin-like growth factor binding protein-3: factors affecting binary and ternary complex formation. Growth Regulation 6 42-47.

Hossenlopp P, Segovia B, Lassarre C, Roghani M, Bredon M \& Binoux M 1990 Evidence of enzymatic degradation of insulin-like growth factor-binding proteins in the $150 \mathrm{~K}$ complex during pregnancy. Journal of Clinical Endocrinology and Metabolism 71 797-805.

Kanety H, Karasik A, Klinger B, Silbergeld A \& Laron Z 1993 Longterm treatment of Laron type dwarfs with insulin-like growth factor-I increases serum insulin-like growth factor-binding protein-3 in the absence of growth hormone activity. Acta Endocrinologica 128 144-149.

Kupfer SR, Underwood LE, Baxter RC \& Clemmons DR 1993 Enhancement of the anabolic effects of growth hormone and insulin-like growth factor-I by use of both agents simultaneously. Journal of Clinical Investigation 91 391-396.
Lemmey AB, Glassford J, Holly JMP \& Pell JM 1994 Regulation of insulin-like growth factor (IGF) binding protein-3 mRNA levels by a single dose of growth hormone (GH) or IGF-I. Journal of Endocrinology (Suppl) 143 P85 (Abstract).

Lewitt MS, Saunders H \& Baxter RC 1993 Bioavailability of insulinlike growth factors (IGFs) in rats determined by the molecular distribution of human IGF-binding protein-3. Endocrinology 33 1797-1802.

Mason HD, Cwyfan-Hughes SC, Heinrich G, Franks S \& Holly JMP 1996 Insulin-like growth factor (IGF)-I and -II, IGF binding proteins and IGF binding protein proteases are produced by normal and polycystic human ovaries. Journal of Clinical Endocrinology and Metabolism 81 276-284.

Menon RK, Arslanian S, May B, Cutfield WS \& Sperling MA 1992 Diminished growth hormone-binding protein in children with insulin-dependent diabetes mellitus. Journal of Endocrinology and Metabolism 74 934-938.

Tanner JM 1962 Growth at Adolescence. Oxford: Blackwell.

Taylor AM, Dunger DB, Grant DB \& Preece MA 1988 Somatomedin$\mathrm{C} /$ IGF-I measured by radioimmunoassay and somatomedin bioactivity in adolescents with insulin-dependent diabetes compared with puberty matched controls. Diabetes Research 9 177-181.

Taylor AM, Dunger DB, Preece MA, Holly JMP, Smith CP, Wass JAH, Patel S \& Tate VE 1990 The growth hormone independent insulin-like growth factor-I binding protein BP-28 is associated with serum insulin-like growth factor-I inhibitory bioactivity in adolescent insulin-dependent diabetics. Clinical Endocrinology 32 229-239.

Received 27 March 1997

Revised manuscript received 24 September 1997 Accepted 5 November 1997 